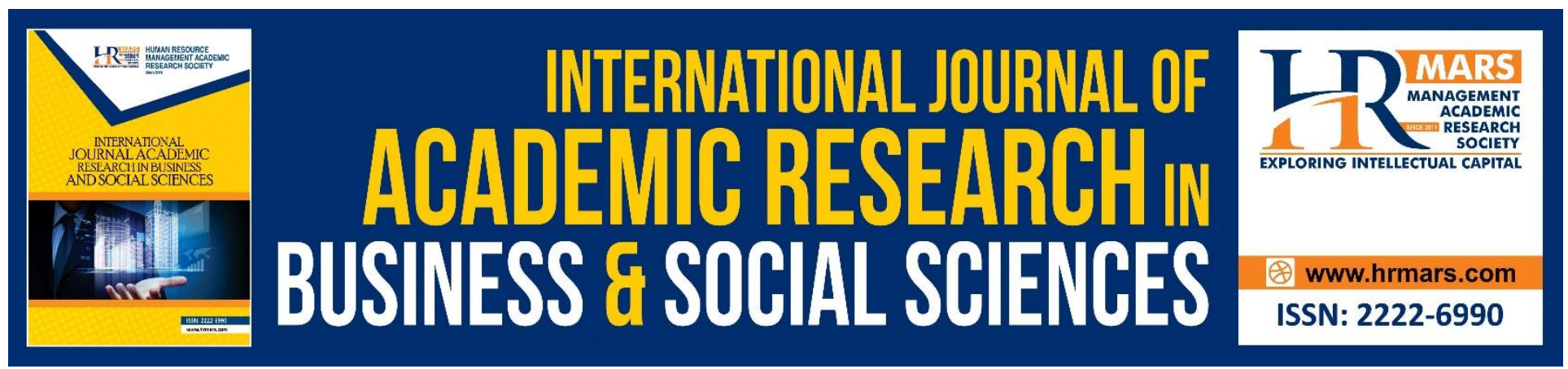

\title{
Predictors and Intervening Variables of Talent Retention
}

\section{Roziah Mohd Rasdi, Nurhazimah Kusnin, Yong See Chen}

To Link this Article: http://dx.doi.org/10.6007/IJARBSS/v8-i12/5007

DOI: 10.6007/IJARBSS/v8-i12/5007

Received: 07 Nov 2018, Revised: 08 Dec 2018, Accepted: 15 Dec 2018

Published Online: 18 Dec 2018

In-Text Citation: (Rasdi, Kusnin, \& Chen, 2018)

To Cite this Article: Rasdi, R. M., Kusnin, N., \& Chen, Y. S. (2018). Predictors and Intervening Variables of Talent Retention. International Journal of Academic Research in Business and Social Sciences, 8(12), 210-220.

\section{Copyright: (C) 2018 The Author(s)}

Published by Human Resource Management Academic Research Society (www.hrmars.com)

This article is published under the Creative Commons Attribution (CC BY 4.0) license. Anyone may reproduce, distribute, translate and create derivative works of this article (for both commercial and non-commercial purposes), subject to full attribution to the original publication and authors. The full terms of this license may be seen

at: http://creativecommons.org/licences/by/4.0/legalcode

Vol. 8, No. 12, 2018, Pg. 210 - 220

http://hrmars.com/index.php/pages/detail/IJARBSS

JOURNAL HOMEPAGE

Full Terms \& Conditions of access and use can be found at http://hrmars.com/index.php/pages/detail/publication-ethics 


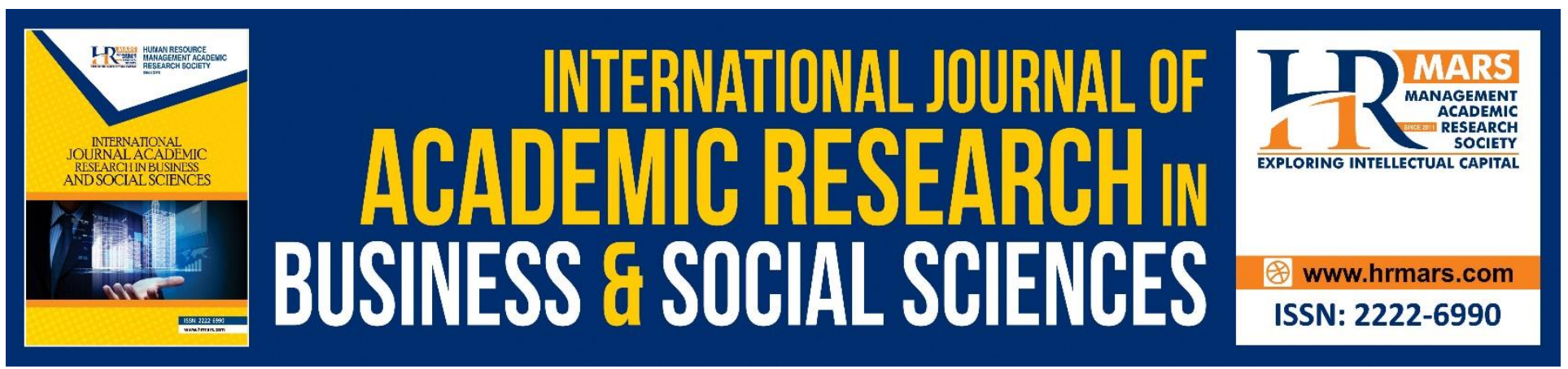

\title{
Predictors and Intervening Variables of Talent Retention
}

\author{
Roziah Mohd Rasdi, Nurhazimah Kusnin, Yong See Chen \\ Faculty of Educational Studies, Universiti Putra Malaysia, 43400 UPM Serdang, Selangor Darul \\ Ehsan, Malaysia
}

\begin{abstract}
Retaining the best talent is one of the major factors towards achieving a high-income nation, and it is critical to organizational success. Organizations have introduced various strategies to enhance employee retention, and efforts should be targeted at valuable, contributing employees such as the high skilled workers. Failure to retain the best talent in organization implicated substantial losses to organization in terms of investment, assets, and destruct social and communication structures as well as affect other employees' morale and work behaviour. Thus, it is imperative to investigate the predictors of talent retention that serve as the engagement and motivational drivers for employee to retain in an organization. Our review of related literature found that potential predictors such as high performance work system, job embeddedness and work life balance have been associated with employee's inclination to remain in organization. Intervening factors such as intrinsic rewards and generational cohort are found to influence the relationships between the predictors and talent retention.
\end{abstract}

Keywords: Talent Retention, Talent Management, Professionals, High Performance Work System

\section{The Scenario}

Talent retention is of strategic importance for organizations to have the potential of sustained competitive advantage. Organizations are facing severe difficulties recruiting and retaining the necessary talent (Scullion, Caliguiri, \& Collings, 2008), and the challenges are more serious for professionals in emerging markets (Tymon Jr, Stumpf, \& Doh, 2010; Devine \& Syrett, 2014). Growing organizations needed to pay as much attention to how they managed their brightest employees as they did on any other corporate resources. These talent are worth fighting for and the supply of talent would decrease while demand would rise.

Changes in psychological contract between organizations and their employees where employees no longer believe that they can depend on organizations for job security has resulted in people feeling less loyalty to their organization, and therefore being more willing to leave for another organization. 
Selden, Schimmoeller, and Thompson (2013) noted that today's employees are leaving employers too soon after joining the organization, which represents substantial organizational investments in recruiting and training that are never realized. Similarly, as the managerial ranks retire, the challenges for organizations are substantial because of the relatively larger financial investment in managers and professionals, as well as their relatively greater impact on their organizations (D'Amato \& Herzfeldt, 2008).

The economic downturn of 2008 to 2009 has brought effect on the retention challenges for professionals in Malaysia. Their value has increased when businesses reduce their labor costs by laying-off unskilled and semi-skilled workers. According to the global management consulting firm McKinsey \& Company, a thirty-three percent rise in the demand for talented employees is expected over the next fifteen years with a corresponding fifteen percent drop in supply (Earle, 2003). The shift accelerated in 2006 when two experienced workers left the workforce for everyone who entered it (Eisner, 2005).

Referring to the local scenario, the highlights on the Malaysian workforce in the 10th Malaysia Plan (2011) have seen tremendous amount of job were created for skilled positions, with manufacturing sector taking the leading role, followed by the ICT industry. The shortage of skilled labour in these industries is one of the primary obstacles to growth in the sectors. Malaysia is ranked 36th out of 60 countries on the Global Talent Index compiled by the Economist Intelligence Unit in 2009, and it was projected to drop to 39th place by 2015 (http://oxfordbusinessgroup.com/full content/reportmalaysia-2012). This scenario further reflects the challenges to retain talent among skilled workers in these sectors.

\section{The Complexities of Associated Factors in Managing Talent}

Organizations are faced with a scarcity issue and have begun thinking carefully about how to retain and develop the employees they have. According to Benish Hussain Janjua (2014), one of the most used ways of retaining employees is compensating them more than they are earning. However, after some years, the competition will be fierce and having the best talent in the organization will be a challenge. Furthermore, the western's rewards and incentives structure may not be generalized in Malaysia, since Malaysia cultures are much more collectivist. Malaysian value trust and harmony in their relationship between employer and employee or colleagues; and a deep understanding of moral values. The wealth of the company and the groups inside are more important than the individual's.

The complexity of the internal organizational process such as hiring, inefficient human resource management systems, and systems lack flexibility; all these processes and mechanism of related high performance work practices created challenges in retaining skilled workers in organizations. In addition, Deery (2008) and Maxwell (2005) found that conflict between work and life has influenced employees' decision to remain with the organization. Bhatnagar (2007) also suggests that the intrinsic rewards associated with work engagement may lead to high retention, however she found that the variable has been generally neglected in discussions of retention in emerging markets. In total, 
INTERNATIONAL JOURNAL OF ACADEMIC RESEARCH IN BUSINESS AND SOCIAL SCIENCES Vol. 8, No. 12, Dec, 2018, E-ISSN: 2222-6990 @ 2018 HRMARS

research that investigates the degree to which skilled workers' engagement in their work might influence retention in organizations are sparse.

To retain talent, organizations must also understand the needs of today's diverse workforce, in particular the differences in values, beliefs and attitudes between generations. Failure to embrace these differences will result in not only having limited talent, but also employees who are not as engaged as they could be (Selden et al., 2013).

The need for effective talent management is gaining attention in the area of cross-cultural influences on work motivation and job performance (Tymon, 2009). Yet, research that investigates the degree to which professional employees' engagement in their work might influence retention is lacking. In addition, most studies on talent retention have focuses on the general employees and less consider the differences of generational cohort (Mitchell, Holtom, \& Lee, 2001). As a result, studies tend to generalize that all strategies work for all generations of employees. To understand the complete picture of the relationships between the predictors and talent retention, it is important to consider the existence of intervening variables that impact the relationships. Some of the variables which have been employed by previous researchers are generational cohort, intrinsic rewards, employees' engagement and trust. To retain talent, organizations must understand the needs of today's diverse workforce. Failure to embrace these differences will result in not only having limited talent, but also employees who are not as engaged as they could be.

Based on the above discussion, we aim to provide insights on the issue of talent retention by suggesting strategies to engage talented human resource to the organization. We discuss based on reviews of related conceptual and empirical papers in the area of talent management, career management and performance management. References and sources were obtained from our literature search using the university's library databases. Several resourceful databases where we gathered our materials are Emerald, Springer Link, Science Direct, Sage and JSTOR Journals. We notice that the majority of the references are based on the American and Europe experiences. It should be noted that the findings of our reviews could not be generalized to the local Malaysian context due to the diversity and dynamism of cultural influences. We also conclude that the references in respect of talent management based on the Malaysian experience are still lacking.

The significance of study includes a range of actions at both the private sector and organizational level. By focusing on generational differences in these relationships, the findings have implications for policies and practices of talent retention in different age groups. Research into the retention of talented staff is ongoing and the findings from such research shall put forward strategies for industry consideration. Such findings are most informative and perhaps suggest ramifications for the way we view the retention issue in the organizations.

\section{Is Sector a Factor in Managing Talent?}

In the studies of talent management, sector is of particular interest as some researchers contend that the work environment, attitudes, and behaviors of public and private sector employees differ from 
another (Rainey, 2003; Selden et al., 2013). For example, private organizations typically have higher turnover rates than public sector organizations, which may reflect that private sector employees are more exposed to risk than individuals working in the public sector. On top of that, scholars have noted that the differences are from the hiring procedure and compensation formation processes (Belman \& Heywood, 1989). The complexity of the hiring process, inefficient human resource management systems, and systems lack flexibility; all these lead to the importance of examining whether or not HPWS practices are impacting the behaviors of private sector professionals. Jackson and Schuler (1995) found that larger organizations were more likely to adopt and implement HPWS than smaller organizations.

\section{Predictors, Mediator and Moderator of Talent Retention}

Organizations can adopt variety of strategies to retain their talent including increasing compensation and benefits, promotions, opportunities to learn, special assignments and status incentives. There are also a number of non-monetary rewards organizations often employ to retain valued employees, such as increased flexibility in work-at-home options, control over their schedules and additional opportunities to develop skills and knowledge during work time or through employer-funded educational programs. Our reviews of literature suggest the following factors.

\section{High Performance Work System}

High performance work system refers to a bundle set of human resource practices that are believed to influence employees' knowledge, motivation and involvement (Messersmith, Guthrie, Ji \& Lee, 2011a; Wu \& Chaturvedi, 2009). These practices typically include recruitment and selection, compensation, training and development, performance management and information sharing (Messersmith et al., 2011; Messersmith, Patel, Lepak, \& Gould-Williams, 2011). Many studies have shown that an integrated system of human resource practices can impact organizational performance, employee commitment, and voluntary employee turnover (Messersmith, 2011; Subramony, 2009; Selden et al., 2013).

High performance work system is drawn from the resource-based view (RBV) as a basis for describing the process through which organizational performance and outcomes, such as productivity, performance, voluntary turnover, growth, and innovation are influenced by the adoption and use of high performance work system (Wright, Dunford, \& Snell, 2001). The RBV suggests that an organization's workforce can be a source of competitive advantage. Thus, forms can develop competitive advantage by acquiring, developing and retaining high quality human resources. Theoretically, organizations that establish HPWS support a commitment-based culture should experience higher employees' retention.

\section{Work-life Balance}

The most recent addition to the research into employee retention is the role that obtaining a balance between work and life has in an employee's decision to remain with the organization. It would appear that the conflict between these important dimensions of human activity can cause both job dissatisfaction and hence an intention to leave the organization as well as causing conflict with family 
members and family activities (Deery, 2008). In various ways, the components of WLB effect job satisfaction and organizational commitment and ultimately lead to employee turnover or retention (Namasivayam \& Zhao, 2007). They also found that work-family conflict related negatively to job satisfaction, but this is mitigated by employees' high commitment to the organization. According to Maxwell (2005), work-life balance strategies such as flexible working hours and arrangements, providing better training, breaks from work and better work support not only address work-life balance issues but also enhance employee retention. Likewise, Doherty (2004) argue that it draws attention to the difference between men and women's working preferences and needs.

\section{Job Embeddedness}

Job embeddedness represents a combination of factors that influence an employee's decision to remain in or leave the organization (Mitchell, Holtom, Lee, Sablynski \& Erez, 2001) and provide a new lens through which to evaluate employees retention (Devine \& Syrett, 2014). It is described as a net or web in which an individual becomes stuck. The theoretical foundation of job embeddedness stems from the field theory (Lewin, 1951) and from embedded figures theories (Witkin, Moore, Goodenough, and Cox, 1977). Embedded figures are immersed in their field and they are connected through many links within their backgrounds and environment (Mitchell, 2001). They are hard to separate from the field and become an intrinsic part of the surroundings.

Job embeddedness consists of three dimensions such as (i) links to other people, teams and groups; (ii) self-perceptions of fit with the job, organization and community; and (iii) perceived sacrifices associated with changing jobs. Job embeddedness has been shown to predict both intent to leave and voluntary turnover (Holtom \& O'Neill, 2004; Bergiel, Nguyen, Clenney, \& Taylor, 2009).

\section{Intrinsic Rewards as Mediator}

Intrinsic rewards associated with performing work is a variable which has been generally neglected in discussions of retention (Bhatnagar, 2007). The construct involves a positive psychological state within individuals and generally accompanied by feelings of passion, energy and enthusiasm (Thomas, 2009). It is based on positively valued experiences that a person gets from doing their work tasks. These feelings reinforce and energize employees' efforts and make work personally fulfilling, suggesting an upward spiral of positive feelings and experiences.

Ghiselli, La Lopa, Bai (2001) found that managers who were more satisfied with the intrinsic components of their jobs, are more satisfied with their life and (relatively) older were less likely to leave their position imminently. Research on intrinsic motivation supports four intrinsic rewards, i.e., experiencing work meaningfulness, choice, progress and competence (Thomas \& Tymon, 2009). When people experience competence, meaningfulness, choice and progress in their work, they report that work is intrinsically rewarding (Thomas, Jansen and Tymon, 2009).

\section{Generational Cohort as Moderator}

The largest demographic shift in the workforce is the existence of the three generations in the workforce; the Baby Boomer generation (1945 - 1964), Generation X (1965 - 1980) and Generation 
$Y$ (post-1980). The profound implication for organizations are managing the coexistence of agediverse workers in a transitioning workplace. The "generational" school of thought maintains that values are imprinted for life by defining historical events that occur as people mature into adulthood.

Cohort theory argues that growing up at about the same time and experiencing these events at about the same point in their development leads to similar values, opinions and life experiences of people within each cohort (Wey Smola \& Sutton, 2002). Traditionalists grew up during the Great Depression and World Wars, hence, were socialized through scarcity and hardship. Baby Boomers, grew up with feelings of prosperity, safety and that anything was possible. They are competitive by nature, loyal and respect authority. Generation $X$ is the child of the workaholic Baby Boomer, and they tend to be self-reliant, individualistic and distrustful of large corporations. They lack in social skills, but they make up for technical ability. Generation $Y$ were raised in a time of economic expansion and prosperity. They are the most technically literate, educated and ethnically diverse generation (Eisner, 2005). These shared events largely influenced the beliefs and attitudes of each generation which subsequently guide members' behavior (Giancola, 2006).

The entrance of Generation $Y$ into the workforce presents both challenges and opportunities. Of all generations, they demand the most from their work environment and are also much more inclined to leave an organization of which they are dissatisfied (Lowe, Levitt \& Wilson, 2011). Organizations are facing with challenges on organizational and workplace changes in order to finding efficient ways to retain Generation Y.

Selden et al. (2013) indicate that organizations may be facing more difficulties retaining the millennia's employees (people born after 1980) than older employees. The millennia's employees often documented need for constant attention and instant information. Studies have suggested that older employees and longer tenured employees quit their jobs less often than their counterparts (Selden et al., 2013; D'Amato, \& Herzfeldt, 2008). D'Amato and Herzfeldt (2008) found that the younger generations are less willing to remain in the same organization and have lower organizational commitment. In particular, Generation X show stronger learning orientation and lower organizational commitment than Baby Boomers. Taken together, these studies show that younger employees are less likely to believe that loyalty pays off. However, the vast majority of these studies were conducted in the US, and these findings cannot be generalized across continents.

Besides that, Festing and Schafer (2014) stated that the same types of psychological contracts cannot fit into different generations in a comparable situation. Psychological contract may be defined as the mutual responsibilities relationship between an employee and an employer whereby each party holds different beliefs in regard to the existence and terms stated in the contract (Rousseau, 1990). She specified that the change in the psychological contract occurs due to different individual's perception. Previous studies determine that differences of generations' cohort of life experiences do influence work behaviors (Takase, Oba \& Yamashita, 2008; Lavoie-Tremblay, O'Brien-Pallas, Gelinas, Desforges \& Marchionni, 2008; Jennings, 2000) and can help organizations increase employees' 
INTERNATIONAL JOURNAL OF ACADEMIC RESEARCH IN BUSINESS AND SOCIAL SCIENCES

Vol. 8, No. 12, Dec, 2018, E-ISSN: 2222-6990 C 2018 HRMARS

intention to stay when they consider differences of generational needs into their retaining efforts (Smola \& Sutton, 2002).

\section{Conclusion}

It is imperative to investigate the predictors of talent retention that serve as the engagement and motivational drivers for talent to retain in an organization. Potential predictors such as high performance work system (Messersmith et al., 2011; Subramony, 2009; Selden et al., 2013), job embeddedness (Holtom \& O'Neill, 2004; Bergiel et al., 2009) and work life balance (Namasivayam, \& Zhao, 2007; Deery, 2008) have been associated with employee's inclination to remain in organization. To enhance understanding of the complexities of associated factors to talent retention, this study incorporates intrinsic rewards as mediator (Bhatnagar, 2007) and generational cohort as moderator (Selden et al., 2013; D'Amato \& Herzfeldt, 2008).

\section{Implication for Practices}

Establishing this new knowledge is instrumental in outlining efficient strategies and interventions for retaining best talent in growing organization. A motivated and committed talent would lead to outcomes such as career success and innovative work behavior.

The study is in line with the vision of the Malaysia Plan to transform the Malaysian economy by reforming the labor market, with special emphasis on retaining the best talent in organization. It proposes a range of actions at both the sector and organizational levels for transformation towards productivity-led growth, where the businesses organizations will be the primary driver of growth and innovation. This study incorporates HPWS as one of the main predictors, thus proposing ways to revising legal and institutional framework for better flexibility in performance management system and enhancing industrial relations.

By focusing on generational differences, the findings of the study have implications for policies and practices of talent retention in different age groups. It also provide insights on an approach of generation-specific HR practices for talent retention.

\section{Acknowledgement}

This study is funded by the Fundamental Research Grant Scheme from the Ministry of Education Malaysia.

\section{References}

Belman, D., \& Heywood, J. S. (1989). Government wage differentials: a sample selection approach. Applied Economics, 21(4): 427-439.

Benish Hussain Janjua, A. G. (2014). the impact of human resource practices on employee commitment and employee retention in telecom sector of Pakistan: exploring the mediating role of employee loyalty. Journal of Business and Management, 16(1): 76-81 doi:10.9790/487X16167681 
INTERNATIONAL JOURNAL OF ACADEMIC RESEARCH IN BUSINESS AND SOCIAL SCIENCES

Vol. 8, No. 12, Dec, 2018, E-ISSN: 2222-6990 @ 2018 HRMARS

Bergiel, E. B., Nguyen, V. Q., Clenney, B. F., \& Taylor, G. S. (2009). Human resource practices, job embeddedness and intention to quit. Management Research News, 32(3): 205-219. doi: 10.1108/01409170910943084

Bhatnagar, J. (2007). Talent management strategy of employee engagement in Indian ITES employees: key to retention. Employee relations, 29(6): 640-663. doi:10.1108/01425450710826122

D'Amato, A., \& Herzfeldt, R. (2008). Learning orientation, organizational commitment and talent retention across generations: A study of European managers. Journal of Managerial Psychology, 23(8): 929-953. doi: 10.1108/02683940810904402

Deery, M. (2008). Talent management, work-life balance and retention strategies. International Journal of Contemporary Hospitality Management, 20(7): 792-806. doi:10.1108/09596110810897619

Devine, M. \& Syrett, M. (2014). Managing Talent. The Economists. Profile Books Ltd, Bungay, Suffolk. Doherty, L. (2004). Work-life balance initiatives: implications for women. Employee Relations, 26(4): 433-452.

Earle, H. A. (2003). Building a workplace of choice: Using the work environment to attract and retain top talent. Journal of Facilities Management, 2(3): 244-257.

Eisner, S.P. (2005). Managing generation Y. S.A.M Advanced Management Journal, 70(4): 4-15.

Festing, M., \& Schafer, L. (2014). Generational challenges to talent management: A framework for talent retention based on the psychological-contract perspective. Journal of World Business, 49, 262-271. doi.10.1016/j.jwb.2013.11.010

Giancola, F. (2006), The generation gap: more myth than reality?, Human Resource Planning, 29(4): 32-7.

Ghiselli, R., La Lopa, J., Bai, B. (2001). Job satisfaction, life satisfaction and turnover intent: among food-service managers. Cornell Hotel and Restaurant Administration Quarterly, 42: 28-37.

Holtom, B. C., \& O'Neill, B. S. (2004). Job embeddedness: A theoretical foundation for developing a comprehensive nurse retention plan. Journal of Nursing Administration, 34(5): 216227.Jackson, S. E., \& Schuler, R. S. (1995). Understanding human resource management in the context of organizations and their environments. Strategic Human Resource Management, 46, 237-264.

Jennings, A. T. (2000). Hiring Generation-X. Journal of Accountancy, 189, 55-59.

Lavoie-Tremblay, M., O’Brien-Pallas, L., Gelinas, C., Desforges, N., \& Marchionni, C. (2008). Addressing the turnover issue among new nurses from a generational viewpoint. Journal of Nursing Management, 16, 724-733.

Lewin, K. (1951). Field theory in social science: selected theoretical papers (Edited by Dorwin Cartwright. Lockwood, N. R. (2007). Leveraging employee engagement for competitive advantage. 2007 SHRM Research Quarterly, 52(3): 1-12.

Lowe, D., Levitt, K. J., \& Wilson, T. (2011). Solutions for retaining Generation Y's employees in the workplace. Engineering Management Review, IEEE, 39(2): 46-52. doi:10.1109/EMR.2011.5876174. 
INTERNATIONAL JOURNAL OF ACADEMIC RESEARCH IN BUSINESS AND SOCIAL SCIENCES

Vol. 8, No. 12, Dec, 2018, E-ISSN: 2222-6990 @ 2018 HRMARS

Maxwell, G. A. (2005). Checks and balances: the role of managers in work-life balance policies and practices. Journal of Retailing and Consumer Services, 12(3): 179-189. doi:10.1016/j.jretconser.2004.06.002

Messersmith, J. G., Guthrie, J. P., Ji, Y. Y., \& Lee, J. Y. (2011a). Executive turnover: the influence of dispersion and other pay system characteristics. Journal of Applied Psychology, 96(3): 457. doi: 10.1037/a0021654

Messersmith, J. G., Patel, P. C., Lepak, D. P., \& Gould-Williams, J. S. (2011). Unlocking the black box: exploring the link between high-performance work systems and performance. Journal of Applied Psychology, 96(6): 1105. doi:10.1037/a0024710

Mitchell, T. R., Holtom, B. C., Lee, T. W., Sablynski, C. J., \& Erez, M. (2001). Why people stay: Using job embeddedness to predict voluntary turnover. Academy of management journal, 44(6): 1102-1121. doi: $10.2307 / 3069391$

Subramony, M. (2009). A meta-analytic investigation of the relationship between HRM bundles and firm performance. Human resource management, 48(5): 745-768. doi:10.1002/hrm

Takase, M., Oba, K., \& Yamashita, N. (2009). Generational differences in factors influencing job turnover among Japanese nurses: An exploratory comparative design. International Journal of Nursing Studies, 46, 957-967. doi.10.1016/j.ijnurstu.2007.10.013

Mitchell, T. R., Holtom, B. C., \& Lee, T. W. (2001). How to keep your best employees: Developing an effective retention policy. The Academy of Management Executive, 15(4): 96-108.

Namasivayam, K. \& Zhao, X. (2007). An investigation of the moderating effects of organizational commitment on the relationships between work-family conflict and job satisfaction among hospitality employees in India. Tourism Management, 28(5): 1212-1223. doi:10.1016/j.tourman.2006.09.021

Rainey, H. G. (2003). Understanding and managing public organizations (Third Edition). John Wiley \& Sons. San Francisco.

Rousseau, D. M. (1990). New hire perceptions of their own and their employer's obligations: A study of psychological contracts. Journal of Organizational Behavior, 11(5), 389-400.

Scullion, H., Caliguiri, P., \& Collings, D. (2008). Call for papers: Global talent management, Journal of World Business, 43: 128-129.

Selden, S., Schimmoeller, L., \& Thompson, R. (2013). The influence of high performance work systems on voluntary turnover of new hires in US state governments. Personnel Review, 42(3): 300-323. doi:10.1108/00483481311320426

Smola, K. W., \& Sutton, C. D. (2002). Generational differences: Revisiting generational work values for the new millennium. Journal of Organizational Behavior, 23(4), 363-382.

Subramony, M. (2009). A meta-analytic investigation of the relationship between HRM bundles and firm performance. Human Resource Management, 48(5): 745-768. doi:10.1002/hrm

The Report: Malaysia. (2012). http://oxfordbusinessgroup.com/full content/report-malaysia-2012

Thomas, K. W. Intrinsic motivation at work (2nd ed.). San Francisco: Berrett- Koehler, 2009.

Thomas, K. W., \& Tymon, Jr., W. G. (2009). Work Engagement Profile. Mountain View, CA: CPP.

Thomas, K.W., Jansen, E., Tymon Jr, K.W. (1997). Navigating in the realm of theory: An empowering view of construct development. W.A. Pasmore, R.W. Woodman (Eds.), Research in organizational change and development, Vol. 10JAI Press, Greenwich, CT, pp. 1-30. 
Tymon Jr, W. G., Stumpf, S. A., \& Doh, J. P. (2010). Exploring talent management in India: The neglected role of intrinsic rewards. Journal of World Business, 45(2): 109-121.

Tymon Jr., W. G., et al. Exploring talent management in India: The neglected role of intrinsic rewards. Journal of World Business (2009), doi:10.1016/j.jwb.2009.09.016

Smola, W. K., \& Sutton, C. D. (2002). Generational differences: Revisiting generational work values for the new millennium. Journal of Organizational Behavior, 23(4): 363-382. doi:10.1002/job.147

Witkin, H.A., Moore, C.A., Goodenough, D.A., \& Cox, P.W. (1977). Field-dependent and fieldindependent cognitive styles and their educational implications. Review of Educational Research, 47: 1-64.

Wright, P. M., Dunford, B. B., \& Snell, S. A. (2001). Human resources and the resource based view of the firm. Journal of management, 27(6): 701-721.

Wu, P. C., \& Chaturvedi, S. (2009). The role of procedural justice and power distance in the relationship between high-performance work systems and employee attitudes: A multilevel perspective. Journal of Management. doi:10.1177/0149206308331097 